\title{
The Effect of Tourism Destination Development, Service Quality on Destination Image and Satisfaction and Its Impact on Tourist Loyalty
}

\author{
Mahmud Lahay, Syamsul Bachri, and Wahyuningsih. \\ Tadulako University, Faculty of Economics and Business, Tadulako University, Palu, Indonesia
}

\begin{abstract}
The purpose of this study is to empirically test and explain (1) the effect of tourism destination development on the image of tourism destinations, (2) the effect of service quality on the image of tourism destinations (3) the effect of destination image on tourist satisfaction (4) the influence of destination image on tourist loyalty. (5) the effect of satisfaction on tourist loyalty and (6) the effect of service quality on tourist satisfaction in Togean, Tojo Una-Una Regency, Central Sulawesi, and Wakatobi, Wakatobi Regency, Southeast Sulawesi. This type of research uses Explanatory Research. Hypothesis testing using Partial Least Square Structural Equation Modeling (PLS-SEM). The number of samples is 198 respondents.
\end{abstract}

Keywords: Tourism Destination Development, Service Quality, Destination Image, Satisfaction, Loyalty

\section{INTRODUCTION}

$\mathrm{T}$ ourism is a sector of concern to the central government and local governments, especially for areas with the potential for natural and marine resources. The development of the tourism sector is expected to be a source of Regional Original Income (PAD) and can support and support other economic sectors. The performance achieved by the tourism sector from 2018 to October 2019 experienced an upward trend, but since the tragedy of the Covid-19 pandemic, the first to be significantly affected was the tourism sector. The Large-Scale Social Restriction Policy (PSBB) has resulted in the global tourism sector, including Indonesia, experiencing negative growth. Despite experiencing negative growth at this time, however seller, (2020)predicts that post-Covid-19, the first sector to rise is the tourism sector. The results of the research support this are et al. (2021)explained that rebuilding a more sustainable ecology and the economy as they emerge from the pandemic in the ongoing climate crisis. Likewise, opinionCooper, (2000); Sunaryo, (2013); Silnov \& Tarakanov, (2015; Andrianto \& Sugiyama, (2016; Krasnokutskiy et al., (2016); Cozma \& Coros, (2017; Asmoro \& Aziz, (2020; andKolobova et al., (2021)stressed the importance of tourism development as a growth point with particular attention to problems with tourism infrastructure in the area, which has significant potential. Therefore, after Covid-19, it is essential to redesign the 4 A tourism development, namely: Attractions, Accessibilities, Amenities, and Ancillary Services, so that the number of tourists will increase again by paying attention to health protocols and rearranging tourist routes in a post-Covid-19 destination. (Zulzilah et al., 2019; Pacurar et al., 2021; Agustine \& Prasetyawati, 2020).

Observing the tourism destinations of Togean Island, Tojo Una-Una Regency, Sulawesi Tengah, and Wakatobi tourism destinations, Wakatobi Regency, Southeast Sulawesi, has been supported by the development of Attractions, Accessibilities, Amenities, and Ancillary Services. However, in terms of Accessibilities, especially in terms of accessibility, namely the means of transportation to the destination. The number of visitors before Covid-19 for these two destinations was relatively high. According to Central Bureau of Statistics of Tojo Una Una Regency (2018) has recorded the number of foreign tourists as many as 5,378 people and 7,617 domestic tourists and Wakatobi, according to the Central Bureau of Statistics of Wakatobi Regency (2018), much higher, namely: for foreign tourists as many as 6,420 people and for domestic tourists as many as 19,035 people.

Each of these destinations has advantages; one of the attractions is the beauty of the underwater, clear, surrounded by islands, coral reefs that are still well preserved, snorkeling (surface diving), or skin diving (shallow diving). Another uniqueness that it has is that on Togean Island, there is a bridge made of wood along 1 (one) km that connects Papan Island and Malenge Island; tourists. Tourists can enjoy the beautiful coral along the bridge's bridge trajectory. Likewise Wakatobi, also has a uniqueness, namely the National Marine Park, which can be used as an educational tour for national and foreign researchers.

Observing the description of the research results above, tourism can be classified as a service business. Therefore, a factor that tourism business actors must not ignore is how to improve the quality of services in the destination area. Research on the tourism sector's service quality explains a strong relationship between tourist expectations, tourist motivation, tourism quality, tourist satisfaction, tourist complaints, and tourist loyalty. Chi \& Qu, 2008; Aunalal et al 2017; andGadoo, 2017). In line with the research results, Kong et al. (2020)stated that the destination and tourist satisfaction image had a positive and significant effect on destination loyalty. This is supported by research conducted by \& Le (2020); Cai et al. (2021); Bae \& Chang 
(2021); and Alvina \& Danang (2021), trying to analyze the tourism promotion strategy empirically by prioritizing a clean/healthy B\&B (bed and breakfast) strategy for tourism recovery after the first wave of Covid-19. It can be emphasized that the New Normal Era Tourism strategy is more concerned with tourism service providers, namely Cleanliness, Health, and Security. According to ASITA (Tourism Industry Association, 2020). Tourism Industry in the New Normal Era to complement the service quality of Nature factors: fresh air (Fresh Air), clean \& hygienic (Clean \& Hygiene), and avoid crowds (Avoid Crowd) to guarantee the quality of service in tourism destinations.

\section{LITERATURE REVIEW}

\section{Relationship between Tourism Destination Development and Destination Image}

according to Cooper (2000) and Sunaryo (2013) explained that the tourism destination development framework consists of the main components, namely Attraction, Accessibility, Amenities, Ancillary Service (Public Facilities). Suwena (2010); Sunaryo, (2013) and Sugiama, (2011) explained (a) attractions or Tourist Attractions (ODTW) are significant components in attracting tourist arrivals, (b) tourism accessibility is intended as all facilities that provide convenience for tourists to reach a destination or related tourist destination, (c) Amenities include a series of facilities to meet the needs of accommodation (lodging), the provision of food and beverages, entertainment venues (entertainment), shopping places (retailing) and other services, and (d) Ancillary Service is more directed to the availability of public facilities and facilities used by the public. Tourists who also support the implementation of tourism activities such as banks, ATMs, telecommunications, hospitals, etc.

Study Krasnokutskiy et al. (2016)measuring the leading indicators of the development of tourism destinations found that the availability of transportation facilities, communication, trade relations, infrastructure development, recreation area improvement, and the development and formation of international tourism use by increasing the competitive features of innovative technologies, so that tourists easily find applications, so that the development of the sector tourism can stimulate the growth of other economic sectors. The same research was conducted byAndrianto \& Sugiyama (2016), Khotimah \& Wilopo (2017), and Cosma \& Coros (2017). The researcher concludes that the development of tourism destinations is proven to shape the image of the goal, which is predicted that tourist arrivals will increase due to the rehabilitation of tourist attractions, sustainable infrastructure improvements and improving the quality of accommodation services, and environmental risks. Based on the description above, the research hypothesis is proposed as follows.

\section{H1: The development of tourism destinations has a significant effect on the image of tourism destinations.}

\section{Relationship between Service Quality and Destination Image}

Santouridis \& Trivellas (2010) state that service quality can be measured using a gap approach between tourists' expectations and perceptions, characterized by five dimensions: Tangibles, Reliability, Responsiveness, Assurance, and Empathy (Hui \& Zheng, 2010). Many studies have revealed that service quality affects the image of a destination and plays a vital role in destination selection(Beerli \& Martin, 2004). In addition, research that measures service quality on the image of the destination is carried out byAunalal et al. (2017), which reduces the theoretical concept Parasuraman et al. (1985)implemented in tourism by measuring service quality 5 dimensions, namely: (1) Reliability, (2) Responsiveness, (3) Assurance, (4) Empathy, and (5) Tangible ( Tangibles). The test results show that service quality provides empirical support for the image of the destination. In line with research (Ryu et al., 2012; Saragih, 2015 and God, 2019)found that service quality can positively affect the image of a tourist village destination, and the higher the service quality, the higher the destination image. Based on the description above, the research hypothesis is proposed as follows.

H2: Service Quality has a significant effect on the Image of Tourism Destinations

\section{Relationship between Destination Image and Tourist Satisfaction}

Tourism image by)Pitana \& Surya (2009) believes that tourists have about the products or services that tourists buy or will buy. The idea of a destination is formed from experience or facts to become a solid motivating factor or driving force for tourist trips to a tourism destination. The image of a goal based on tourist ratings can vary from one person to another. Beerli \& Martin (2004) said that the idea of a destination is one of the critical factors, which can influence tourists' decisions about destination choices.

Several previous studies have defined the concept of destination image as the overall individual perception or total impression of a tourist destinationCrompton, (1979) and Chen \& Tsai, (2007). Image is defined as a visitor's perception of a tourist destination as a destination. In line with opinionBaloglu \& McCleary (1999), the focus of destination image is more on the mental image of the goal (estimation process for choosing tourist sites), affective factors (beliefs and attitudes of destination destinations, and conative factors (choice of one's final destination). Baloglu \& McCleary, (1999)namely: the quality of the experience, the impression of the attraction, and the quality of the environment. Different research conducted byDel Bosque \& San Martin (2008) introduces the dimensions of the destination image and adds one indicator, namely the impression on the socio-economic environment.

The same research was conducted by Qu et al. (2011), measuring the image of the destination into 5 indicators, 
namely: (1) Quality of experience, (2). Tourist attraction, (3). Environment and infrastructure, (4) Entertainment/outdoor activities, and (5). Local cultural traditions. WhereasArtuğer et al. (2013) divide the dimensions of the effective image into three, namely a lively city, an exciting city, and a pleasant city. Based on the description above, it can be concluded that there are two main elements of the destination image, namely (a) cognitive elements and (b) emotional elements. Kotler \& Keller (2016) and adopt destination Image indicators (Artuğer et al., 2013). StudySun et al. (2013), Hanif et al. (2016), Ramseook et al. (2015), and Ummasyaroh \& Setiawan (2018)proves that there is a significant effect of destination image on tourist satisfaction. A positive perception of a destination image causes high satisfaction, and a negative image causes dissatisfaction or displeasure. Based on the description above, the research hypothesis is proposed as follows.

\section{H3: Destination Image has a significant effect on Tourist Satisfaction at Tourism Destinations}

\section{Relationship between Destination Image and Tourist Loyalty}

Study Ramseook et al. (2015) andAunalal et al. (2017) prove that destination image supports tourist loyalty to tourism destinations, and destination image has a strong significant and positive effect on tourist loyalty and provides empirical support. In addition, researchArtuğer et al. (2013) and $\mathrm{Yu} \&$ Hwang (2019) explained that the destination's image influences tourists' behavior, such as intending to revisit, recommending it to others, or revisiting a tourism destination. Artuğer et al. (2013), through their research, also proves a strong and positive relationship between destination image and destination loyalty and shows that cognitive image has a greater influence on loyalty than effective image. Based on the description above, the research hypothesis is proposed as follows.

\section{H4: Destination Image has a significant effect on Tourist Loyalty in Togean Tourism Destinations.}

\section{Relationship between Tourist Satisfaction and Tourist Loyalty}

Tourist satisfaction is the activation of positive feelings for the tourist experience after visiting a tourism destination. Oliver \& DeSarbo, (1988); Chen \& Tsai, (2007); Prayag \& Ryan, (2012). Research conducted byoban (2012), Ramseook et al. (2015), Khuong et al. (2016), and Ummasyaroh \& Setiawan (2018)has proven that satisfaction directly affects tourist loyalty. This research indicates that tourists feel satisfied when visiting these two destinations and tend to make repeat visits to gain tourist experiences, especially with the support of the many tourist attractions in these destinations. This research supports researchLesmana \& Hasbiyah (2019), which shows that there is a positive influence between satisfaction and tourist loyalty; general satisfaction and attributes also have a positive effect on tourist satisfaction and intention to return and willingness to recommend a positive effect on tourist loyalty. Based on the description above, the research hypothesis is proposed as follows.

H5: Tourist satisfaction has a significant effect on Tourist Loyalty to Tourism Destinations.

\section{Relationship between Service Quality and Tourist Satisfaction}

Khuong et al. (2016) and Hermawan (2018) prove that service quality affects tourist satisfaction. This supports previous researchIhshani, (2005) and Faizal (2005). In addition, the correlation between the two research variables is positive, meaning that the better the quality of service provided by the manager, the greater the satisfaction of visitors; on the contrary, the worse the quality of service provided, the lower the satisfaction of visitors. Al-Ababneh, (2013)found that service quality (destination facilities, destination accessibility, destination attractiveness) was a significant predictor of tourist satisfaction. The same research byKhan et al. (2017)found that quality (quality of accessibility, accommodation, place) contributes directly to tourist satisfaction. Different from researchAunalal et al. (2017) measures the quality of service on tourist satisfaction with 5 (five) dimensions, namely: 5 dimensions namely: (1) Reliability, (2) Responsiveness, (3) Assurance, (4) Empathy (Empathy). ), and (5) Tangibles. Although the dimensions are different, the findings are the same. Namely, the 5 (five) dimensions affect tourist satisfaction. Thus, fineAunalal et al. (2017), Khan et al. (2017) and-Ababneh, (2013)suggest that tourism managers pay attention to and increase tourist satisfaction with the various dimensions of its formation. Based on the description above, the research hypothesis is proposed as follows.

H6: Service Quality has a significant effect on Tourist Satisfaction at Tourism Destinations.

The conceptual framework

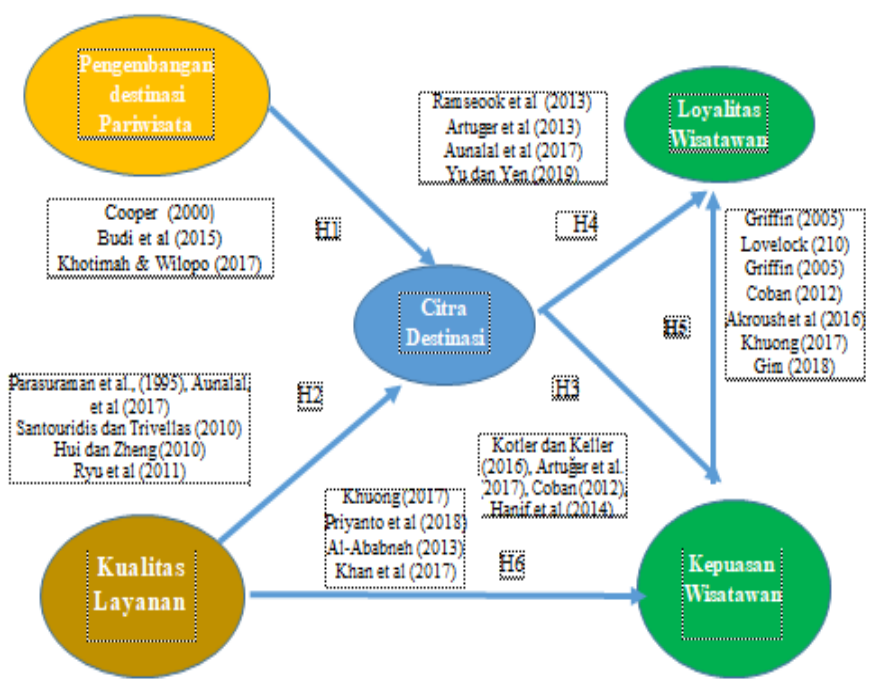

Figure 1. The conceptual framework 


\section{METHODOLOGY}

This type of research includes the type of Explanatory research. Explanatory is a type of research that highlights the relationship between research variables and tests hypotheses that have been formulated previously (now, 2017). The same opinion was expressed by (Sugiyono 2017) that explanatory research explains the position between the variables studied and the relationship between one variable and another. Now, (2017), when viewed from the research objectives, this research is descriptive and explanatory studies through hypothesis testing. The descriptive study aims to systematically describe situations, problems, phenomena, services/programs, or provide information about people's living conditions or describe attitudes towards a problem. At the same time, explanatory research aims to explain why and how the relationship between two or more aspects of a situation or phenomenon. Sukmadinata (2009)argues that qualitative data is data in words, sentences, and pictures. Qualitative data can be converted into quantitative data by way of scoring. Examples are very good, good, not very good, not good, or strongly agree, agree, undecided, disagree, strongly disagree, always, often, sometimes, rarely, and never. Furthermore, quantitative research is research whose data is quantitative, so that the data analysis uses quantitative analysis (inference).

\section{Sampling and Data Collection}

The population in this study were all tourists, namely foreign tourists (Wisman) and domestic tourists (Wishnu) who visited Togean and Wakatobi tourism destinations. The population of visitors to the Togean tourism destination is 12,995 people (Wishnu: 7,617, Wisman: 5,378). Meanwhile, the population of Wakatobi tourists is 25,455 people (Wisnu: 19,035 people, foreign tourists 6,420 people). The number of samples in this study was 198, with 99 in Wakatobi, Southeast Sulawesi, and 99 in Togean, Central Sulawesi. The analysis method uses a variance-based Structural Equation Model or called Partial Least Square (PLS). The Partial Least Square (PLS) model consists of structural equations and measurement equations. Structural model measurements can be summarized in the table below(Leguina, 2015):

Table 1. Structural Model Measurement

\begin{tabular}{|c|c|}
\hline Criteria & description \\
\hline $\begin{array}{l}\text { R2 Endogenous } \\
\text { Latent Variable }\end{array}$ & $\begin{array}{l}\mathrm{R} 2 \text { value of } 0.67 \text { is categorized as substantial } \\
\mathrm{R} 2 \text { value of } 0.33 \text { is categorized as moderate } \\
\mathrm{R} 2 \text { value of } 0.19 \text { is categorized as weak (Chin, 1998) } \\
\mathrm{R} 2 \text { value of }>0.7 \text { is categorized as strong (sarwono) }\end{array}$ \\
\hline $\begin{array}{l}\text { 'Estimate for } \\
\text { path coefficient }\end{array}$ & $\begin{array}{l}\text { The values estimated for the path relationships in the } \\
\text { structural model should be evaluated in terms of the } \\
\text { strength and significance of the relationships. }\end{array}$ \\
\hline Effect size f2 & $\begin{array}{l}\text { The f } 2 \text { value of } 0.02 \text { is categorized as a weak influence } \\
\text { of latent predictor variables (exogenous latent } \\
\text { variables) at the structural level. } \\
\text { The f } 2 \text { value of } 0.15 \text { is categorized as a sufficient } \\
\text { influence of latent predictor variables (exogenous } \\
\text { latent variables) at the structural level. } \\
\text { The f } 2 \text { value of } 0.35 \text { is categorized as a strong }\end{array}$ \\
\hline
\end{tabular}

\begin{tabular}{|l|l|}
\hline & $\begin{array}{l}\text { influence of latent predictor variables (exogenous } \\
\text { latent variables) at the structural level. }\end{array}$ \\
\hline $\begin{array}{l}\text { The value of Q2 > 0 shows evidence that the observed } \\
\text { values have been reconstructed properly. Thus the } \\
\text { relevance } \\
\text { (Q2 and Q2) } \\
\text { model has predictive relevance. While the value of Q2 }\end{array}$ & $\begin{array}{l}\text { The value of q2 is used to see the relative effect of the } \\
\text { structural model on the measurement of observations } \\
\text { for the latent dependent variable (endogenous latent } \\
\text { variable). }\end{array}$ \\
\hline $\begin{array}{l}\text { Beta value for } \\
\text { path coefficient } \\
\text { on PLS-SEM }\end{array}$ & $\begin{array}{l}\text { The individual path coefficients in the structural model } \\
\text { are interpreted as standard beta coefficients from OLS } \\
\text { (ordinary least square) regression. }\end{array}$ \\
\hline
\end{tabular}

Source: Legian, (2015)

\section{RESULTS INTERPRETATIONS}

\section{Respondent profile}

The frequency and percentage of research respondents are shown in Table 2. The results show that 117 men, or $59 \%$ of men, are more dominant and 81 women or $41 \%$. The dominant age of respondents is between $27-37$ years, as many as 75 people or $38 \%$, while the age of respondents above 47 years is at least only $15 \%$. Then the dominant education level of undergraduate as many as 8 people or $47 \%$, while professional education only 9 people or $4 \%$. Furthermore, judging from the respondent's occupation, 57 people or (29\%), while the work of lecturers is only 5 people or $2 \%$. The details can be presented in Table 2.

Table 2: Summary of the profile of respondents

\begin{tabular}{|c|c|c|c|}
\hline Constructs & Items & Frequency & $\begin{array}{c}\text { Valid } \\
\text { Percent (\%) }\end{array}$ \\
\hline \multirow[t]{2}{*}{ Gender } & Man & 117 & 59.0 \\
\hline & Woman & 81 & 41.0 \\
\hline \multirow[t]{4}{*}{ Age } & $>17-27$ & 48 & 24.0 \\
\hline & $>27-37$ & 75 & 38.0 \\
\hline & $>37-47$ & 46 & 23.0 \\
\hline & $>47$ & 29 & 15.0 \\
\hline \multirow[t]{4}{*}{ Education } & $\begin{array}{l}\text { SMA/SMK/Gy } \\
\text { mnasium }\end{array}$ & 59 & 30 \\
\hline & $\begin{array}{c}\text { Bachelor/Bache } \\
\text { lor degree }\end{array}$ & 87 & 44 \\
\hline & Postgraduate & 43 & 22 \\
\hline & $\begin{array}{l}\text { Professional } \\
\text { Education }\end{array}$ & 9 & 4 \\
\hline \multirow[t]{10}{*}{ Profession } & civil servant & 41 & 21 \\
\hline & self-employed & 57 & 29 \\
\hline & Media & 6 & 3 \\
\hline & Consultant & 16 & 8 \\
\hline & Office workers & 18 & 9 \\
\hline & College student & 10 & 5 \\
\hline & Free Worker & 14 & 7 \\
\hline & Lecturer & 5 & 2 \\
\hline & Traveler & 8 & 4 \\
\hline & Others & 23 & 12 \\
\hline
\end{tabular}




\section{Measurement model}

The validity and reliability test measurement models follow Cronbach Alpha $(\alpha)$ and Composite Reliability (CR). The results show that all indicators are valid and reliable based on the Cronbach Alpha size higher than the accepted value of 0.7 (Kannan \& Tan, 2005). In addition, the results show that all CR values are above 0.7(Tabri \& Elliott, 2012). Construct reliability was met (Table 2). Henceforth, loading for all measurements exceeds the accepted value of 0.5. For both constructs, the dependence on the suggested value $(\alpha)$ and composite reliability (>0.7) is metLegian, (2015).

Table 2: Measurement model results

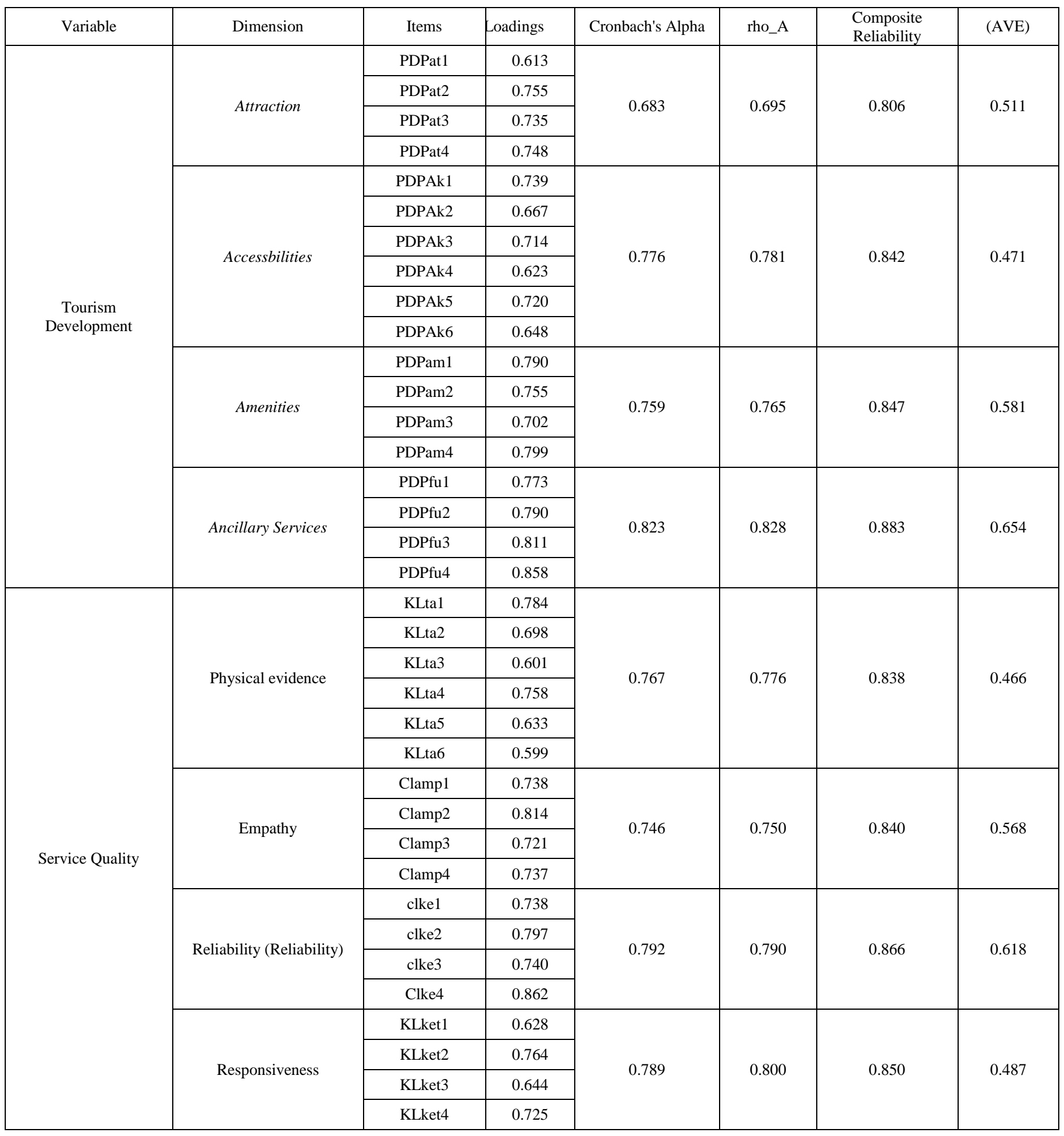




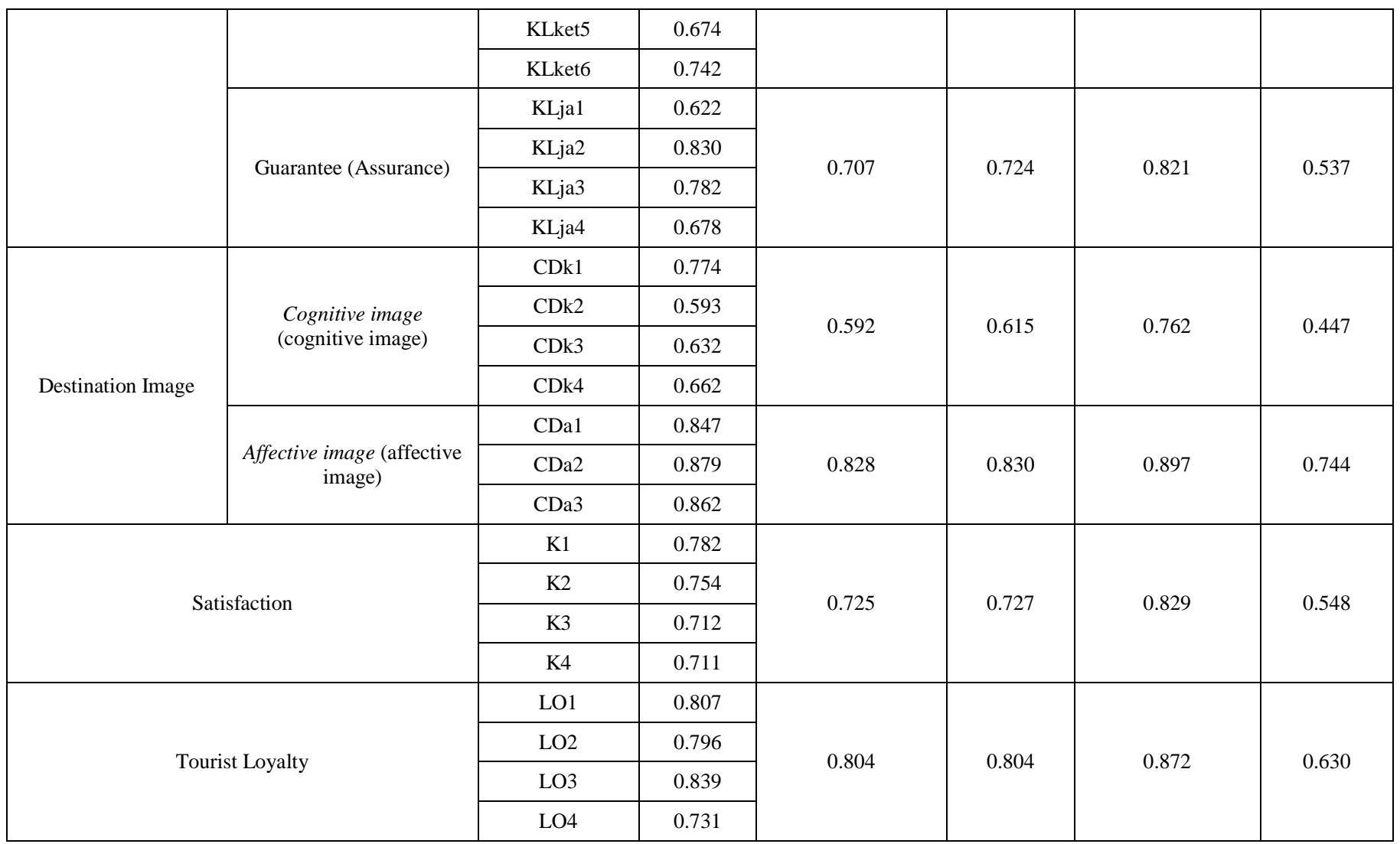

Note: Cronbach Alpha ( $\alpha$ ), Composite Reliability (CR), Average Variance Extracted (AVE)

\section{Structural Model}

Testing the first hypothesis, Tourism Destination Development (PDP) significantly affects Destination Image (CD). The test results prove that the value of $\mathrm{P}$ Values $(0.009)$ $<$ Alpha $(\alpha)(0.05)$ or the value of t-statistics $(2.633)>t$-table (1.652). This study proves that Tourism Destination Development (PDP) has a significant effect on Destination Image (CD), so the first hypothesis can be accepted.

Testing the second hypothesis, Service Quality (KL) significantly affects Destination Image $(\mathrm{CD})$. The test results prove that the value of $\mathrm{P}$ Values $(0.000)<$ Alpha $(\alpha)(0.05)$ or the value of t-statistics (6.723) > t-table (1.652). This study proves that Service Quality (KL) has a significant effect on Destination Image (CD), so the second hypothesis can be accepted.

Testing the third hypothesis, Destination Image (CD) significantly affects Tourist Satisfaction $(\mathrm{KW})$. The test results prove that the value of $\mathrm{P}$ Values $(0.000)<$ Alpha $(\alpha)$ $(0.05)$ or the value of t-statistics (7.76) $>$ t-table (1.652). This study proves that Destination Image (CD) has a significant effect on Tourist Satisfaction (KW), so the third hypothesis can be accepted.

Testing the fourth hypothesis, Destination Image (CD) significantly affects Tourist Loyalty (LW). The test results prove that the value of $\mathrm{P}$ Values $(0.000)<$ Alpha $(\alpha)$ $(0.05)$ or the value of t-statistics (3.75) $>\mathrm{t}$-table (1.652). This study proves that Destination Image (CD) has a significant effect on Tourist Loyalty (LW), so the fourth hypothesis can be accepted.

Testing the fifth hypothesis, Tourist Satisfaction (KW) significantly affects Tourist Loyalty (LW). The test results prove that the value of $\mathrm{P}$ Values $(0.000)<$ Alpha $(\alpha)$ (0.05) or t-statistics (5.75) > t-table (1.652). This study proves that Tourist Satisfaction (KW) has a significant effect on tourist loyalty (LW) so that the fifth hypothesis can be accepted.

Testing the sixth hypothesis, Service Quality (KL) significantly affects Tourist Satisfaction (KW). The test results prove that the P Values $(0.000)<$ Alpha $(\alpha)(0.05)$ or tstatistics (3.98) > t-table (1.652). The results of this study prove that Service Quality (KL) has a significant effect on Tourist Satisfaction (KW) (LW), so the sixth hypothesis can be accepted. 


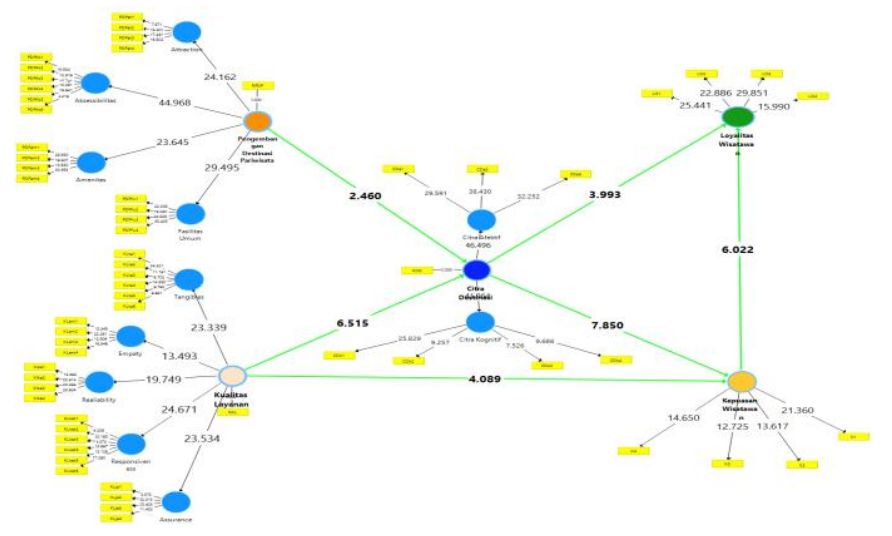

Figure 2: Structural model results

Table 3: Hypotheses testing results

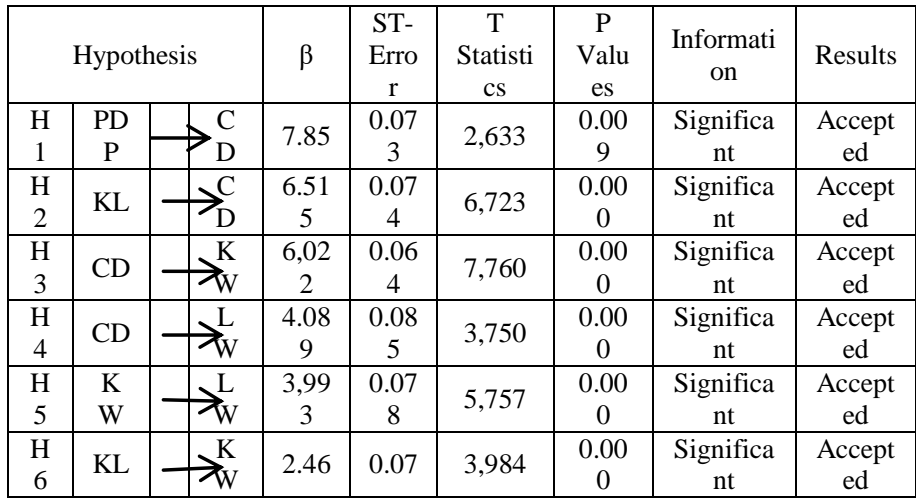

\section{DISCUSSION}

The influence of tourism destination development on the image of tourism destinations

The results of hypothesis testing explain that the development of tourism destinations has a significant effect on the image of Togean tourism destinations, Tojo Una-Una Regency, Central Sulawesi, and Wakatobi, Wakatobi Regency, Southeast Sulawesi. Tourism development is a series of efforts to realize integration in various tourism resources, integrating all forms of aspects outside of tourism that are directly or indirectly related to the continuity of tourism development. The development of tourism destinations must focus on aspects of 4A (Attraction, Accessibility, Amenities, Ancillary Service). The development of these four aspects can be used as a benchmark to measure the quality and image of a tourism destination(Diwangkara et al., 2020).

The findings in this research explain that the development of tourism destinations consists of tourist attractions, accessibility, amenities, and public facilities. It was revealed that foreign tourists and foreign tourists in Togean and Wakatobi tourism destinations visited destinations because they were more concerned with existing tourist attractions than other dimensions. Wakatobi to implement the programs that have been prepared. The results of this study are supported by research conducted by Wanda
\& Pangestuti (2018), which states that in realizing the development of good tourist destinations, it is necessary to improve the quality and quality of these destinations to create a good image of the destination in the eyes of visitors and the public. Zhang et al. (2021) explained that the image of transportation projected by tourism authorities and the image perceived by tourists are important for sustainable tourism development.

The influence of service quality on the image of tourism destinations

The results of hypothesis testing explain that service quality has a significant effect on the image of Togean tourism destinations, Tojo Una-Una Regency, Central Sulawesi, and Wakatobi, Wakatobi Regency, Southeast Sulawesi. Conceptually, according to God (2019), Good service quality has an important meaning for the survival of a tourist area because it can affect the image of the area. This can be explained that positive service quality will have an impact on a positive destination image. In line with the research results conducted byKartawidjaja (2020) and Agustine \& Prasetyawati (2020), the company's image reflects service quality and business reputation has a positive and significant effect on loyalty through the corporate image.

The influence of destination image on tourism tourist satisfaction

The hypothesis test results explain that the image of the destination has a significant effect on tourist satisfaction of Togean tourism, Tojo Una-Una Regency, Central Sulawesi, and Wakatobi, Wakatobi Regency, Southeast Sulawesi. The results of this study are in line with research by Chua et al. (2021), Janchai et al. (2020), Králiková et al. (2020), and \& Le (2020), which concludes that image has a positive effect on tourist satisfaction.

Furthermore, the findings in this research, the influence of destination image on tourist satisfaction is supported by the compatibility between tourists' knowledge about Togean and Wakatobi tourism destinations with the reasons for visiting. The reason most respondents chose was because of the natural attractiveness of tourism destinations. This is reinforced by the results of open-ended questions on the questionnaire and interviews with Wisnu in Togean and Wakatobi tourism destinations, preferring natural attractions, especially beaches. According to respondents, the properties contained in seawater, one of which is believed to overcome viruses, including Covid-19. In addition, some respondents chose nature tourism, such as visiting the mountains during the Covid-19 and post-Covid-19 periods, because the outdoors was considered to reduce the risk of respiratory problems. Osti \& Nava (2020) also stated that mountainous locations were considered safer than seaside destinations and art towns.

Furthermore, the findings of this research also show that during the Covid-19 pandemic, the level of tourist attention increased to the image of the destination that became 
the main concern for tourists, namely the cleanliness of the destination, which was marked by the fulfillment of the implementation of health protocols by policies issued by the government to ensure health, comfort, and safety of tourists. This is in line with the research conducted by Cai et al. (2021) and Suprihatin (2020), which also analyzes tourist behavior during the Covid-19 period. The research results show that tourists have a very good understanding and sensitivity to the importance of identifying the cleanliness of a tourism destination before deciding to visit.

\section{The influence of destination image on tourism tourist loyalty}

The hypothesis test results explain that the image of the destination has a significant effect on the loyalty of Togean tourism tourists, Tojo Una-Una Regency, Central Sulawesi, and Wakatobi, Wakatobi Regency, Southeast Sulawesi. This finding is supported by researchHidayatullah et al. (2020) and Studies (2021), which states that the destination's image, which consists of a cognitive image, unique image, and affective image, affects loyalty through visitor satisfaction. The findings of this research explain that cognitive image has a greater influence than the effective image on tourist loyalty to Togean and Wakatobi tourism destinations. This means cognitive images describe the beliefs and information people have about a place. The cognitive element generally comes from the evaluation of the people who live in that place and the events that occur in that place. These findings are reinforced by Muis et al. (2020)through their research, showing that cognitive image has a greater influence on loyalty than effective image. Based on this, it can be concluded that the behavior of future tourists who judge positively on the image of a tourism destination is likely to revisit and recommend related tourism destinations to others. In addition, researchAunalal et al. (2017) prove that destination image supports tourist loyalty to tourism destinations, and destination image has a strong significant and positive effect on tourist loyalty and provides empirical support. This study is not in line with the findingsRamseook et al. (2015), proving that destination image does not build a significant direct relationship between destination image and loyalty.

On the other hand, researchArtuğer et al. (2013) explained that the destination's image influences tourists' behavior, such as intending to revisit, recommend it to others, or revisit a tourism destination. Artuğer et al. (2013) and Yu \& Hwang (2019), through their research, also prove that there is a strong and positive relationship between destination image and destination loyalty and shows that cognitive image has a greater influence on loyalty than effective image. However, in contrast to the findings made by the authors, that affective image has a greater influence on loyalty than cognitive image.

\section{The influence of tourist satisfaction on tourism tourist loyalty}

The results of hypothesis testing explain that tourist satisfaction has a significant effect on tourist loyalty to
Togean tourism, Tojo Una-Una Regency, Central Sulawesi and Wakatobi, Wakatobi Regency, Southeast Sulawesi. Tourists who have positive experiences and tend to be pleasant have a greater chance of becoming loyal tourists to the Togean tourism destinations, Tojo Una-Una Regency, Central Sulawesi, and Wakatobi, Wakatobi Regency, Southeast Sulawesi, compared to tourists who feel disappointed or dissatisfied. This indicates that the higher the satisfaction of tourists with tourism destinations, the higher the level of loyalty to the related tourism destinations. True loyalty to tourism destinations lies in tourist satisfaction,

Research conducted by Oban (2012), Ramseook et al. (2015), Khuong et al. (2016), and Ummasyaroh \& Setiawan (2018)has proven that satisfaction directly affects tourist loyalty. The same thing was conveyed game (2018)that satisfaction has a direct effect on tourist loyalty. This can be explained by the behavior of tourists who are satisfied after getting a travel experience in a tourism destination; in the future, the behavior or actions are taken such as intending to visit again, say positive things, and recommend to others. The form of the real behavior of tourists loyal to the Togean and Wakatobi tourism destinations can be seen from the quantity of the frequency of their visits. Based on the description of the respondent's characteristics described in the findings of this dissertation research, it is known that most of the respondents have visited 2-4 times to Togean and Wakatobi tourism destinations. This shows that tourists feel satisfied when visiting these two destinations and tend to make repeat visits to gain tourist experiences, especially with the many tourist attractions in these destinations. This research supports researchLesmana \& Nabila (2020), which shows that there is a positive influence between satisfaction and tourist loyalty; general satisfaction and attributes also have a positive effect on tourist satisfaction and intention to return and willingness to recommend a positive effect on tourist loyalty.

The next finding in this research, is that respondents plan to stay for 4-7 days if they visit again after post-Covid19. This is in line with research conducted byWachyuni \& Kusumaningrum (2020), which stated that travel preferences $(78 \%)$, or the majority of respondents stated that they would return to travel. Around $(65 \%)$ will return to travel in the near future, in 0-6 months after the pandemic is declared over; the type of tourism that respondents want is nature tourism (66\%).

The influence of service quality on tourism tourist satisfaction

The results of hypothesis testing explain that service quality has a significant effect on tourist satisfaction of Togean tourism, Tojo Una-Una Regency, Central Sulawesi, and Wakatobi, Wakatobi Regency, Southeast Sulawesi. Conceptually, service quality is one measure of success in providing guarantees for customer satisfaction. Through service quality, a customer can provide an objective assessment to create and increase customer satisfaction and loyalty. Khuong et al. (2016) and Hermawan (2018) prove that service quality affects tourist satisfaction. This supports 
previous research by Ihshani (2005) and Hamzah \& Hariyanto (2015). In addition, the correlation between the two research variables is positive, meaning that the better the quality of service provided by the manager, the greater the satisfaction of visitors; on the contrary, the worse the quality of service provided, the lower the satisfaction of visitors.

Furthermore, Al-Ababneh, (2013)found that service quality (destination facilities, destination accessibility, destination attractiveness) was a significant predictor of tourist satisfaction. The same research byKhan et al. (2017)found that quality (quality of accessibility, accommodation, place) contributes directly to tourist satisfaction. Different from researchAunalal et al. (2017) measuring service quality on tourist satisfaction with 5 (five) dimensions, namely: 5 dimensions, namely: (1) Reliability, (2) Responsiveness, (3) Assurance, (4) Empathy. And (5) Tangibles. The findings state that these 5 (five) dimensions affect tourist satisfaction. Thus, fineAunalal et al. (2017), Khan et al. (2017; Al-Ababneh, (2013), and Prasetya \& Suryadi (2020) suggest that tourism managers pay attention to and increase tourist satisfaction with the various dimensions of its formation.

Furthermore, in this research, the responsiveness dimension gives the greatest contribution to tourist satisfaction. This means that the Responsiveness dimension, with the highest indicator, namely the speed of officers in serving, is perceived by both Wisnu and foreign tourists in increasing satisfaction. (Branch et al., 2021). This finding contradicts the research conducted by banking objects which states that reliability, responsiveness, and empathy have no significant effect on customer satisfaction. Then, Mutiara et al. (2020) also stated that reliability and empathy variables had a positive but not significant impact on consumer satisfaction.

\section{CONCLUSION}

Based on this research, it can be concluded that the development of tourism destinations has a significant effect on the image of Togean tourism destinations, Tojo Una-Una Regency, Central Sulawesi and Wakatobi, Wakatobi Regency, Southeast Sulawesi; Service quality has a significant effect on the image of Togean tourism destinations, Tojo Una-Una Regency, Central Sulawesi and Wakatobi, Wakatobi Regency, Southeast Sulawesi; Destination image has a significant effect on tourist satisfaction in Togean tourism destinations, Tojo Una-Una Regency, Central Sulawesi and Wakatobi, Wakatobi Regency, Southeast Sulawesi; Destination image has a significant effect on tourist loyalty to Togean tourism destinations, Tojo Una-Una Regency, Central Sulawesi and Wakatobi, Wakatobi Regency, Southeast Sulawesi; Tourist satisfaction has a significant effect on tourist loyalty to Togean tourism destinations, Tojo Una-Una Regency, Central Sulawesi and Wakatobi, Wakatobi Regency, Southeast Sulawesi; Service quality has a significant effect on tourist satisfaction in Togean tourism destinations, Tojo Una-Una
Regency, Central Sulawesi and Wakatobi, Wakatobi Regency, Southeast Sulawesi.

The suggestions in this study are to improve tourism supporting infrastructure, accessibility, and attractiveness of destinations are very important to be considered by stakeholders because it will provide the highest contribution to the progress of a tourism destination. The concept of transportation during the Covid-19 pandemic considers three aspects of the transportation-tourism relationship: short distances, shorter distances (time), less energy-intensive, and green transportation that affects breathing (air pollution)paying attention to service quality in the dimension of assurance or service guarantee on timeliness, frequency of air/sea transportation, and ensuring disciplined health protocols during the Covid-19 period (Breakfast and Bed cleanliness).

\section{REFERENCES}

[1] Agustine, M., \& Prasetyawati, YR (2020). The effect of information quality on Instagram and electronic word of mouth on the image of Dapurfit. Public Relations Professional Journal of Public Relations, 5(1), 82. https://doi.org/10.24198/prh.v5i1.23966

[2] Al-Ababneh, M. (nd). Service Quality and its Impact on Tourist Satisfaction. Interdisciplinary Journal of Contemporary Research in Business, 164-177.

[3] Andrianto, T., \& Sugiama, G. (2016). The Analysis of Potential 4A's Tourism Component in the Selasari Rural Tourism, Pangandaran, West Java. 138-144. https://doi.org/10.2991/atf16.2016.21

[4] Artuğer, S., etinsöz, BC, \& Kılıç, . (2013). Makale Anketinte Kullanilacak The Effect of Destination Image on Destination Loyalty: An Application In Alanya. European Journal of Business and Management, 5(13), 2222-2839.

[5] Asmoro, AY, \& Aziz, M. (2020). Potential Development of Setigi as a Tourist Destination. JMK (Journal of Management and Entrepreneurship), $\quad 5(3), \quad 228$. https://doi.org/10.32503/jmk.v5i3.1136

[6] Aunalal, ZI, Kadir, AR, Taba, MI, \& Hamid, N. (2017). The Influence of Service Quality Dimensions, Destination Image, and Satisfaction to Tourist Loyalty in Maluku Province Zany Irayati Aunalal Muh. Idrus Taba. Scientific Research Journal (SCIRJ), 5(6), 71-85.

[7] The Central Bureau of Statistics of Tojo Una Una Regency. (2018). A number of foreign tourist visitors. https://tojounakab.bps.go.id/. accessed February 2020

[8] Wakatobi Regency Central Bureau of Statistics. (2018). A number of foreign tourist visitors. Https://Baubaupost.com, accessed November 2020

[9] Bae, SY, \& Chang, PJ (2021). The effect of coronavirus disease19 (COVID-19) risk perception on behavioral intention towards 'untact' tourism in South Korea during the first wave of the pandemic (March 2020). Current Issues in Tourism, 24(7), 10171035. https://doi.org/10.1080/13683500.2020.1798895

[10] Baloglu, S., \& McCleary, KW (1999). A model of destination image formation. Annals of Tourism Research, 26(4), 868-897. https://doi.org/10.1016/S0160-7383(99)00030-4

[11] Beerli, A., \& Martin, JD (2004). Factors influencing destination image. Annals of Tourism Research, 31(3), 657-681. https://doi.org/10.1016/j.annals.2004.01.010

[12] Branch, K., Sila, I., Yusi, S., Bisnis, JA, \& Sriwijaya, PN (2021). Journal of Applied Economics, Management and Business Analysis of Customer Satisfaction at PT Bank Rakyat Indonesia (Persero) Tbk. Kayuagung Branch Analysis of Customer Satisfaction at The PT Bank Rakyat Indonesia Journal of Applied Economics, Management and Business, 1(4). 
[13] Cai, G., Xu, L., \& Gao, W. (2021). The green B\&B promotion strategies for tourist loyalty: surveying the restart of Chinese national holiday travel after COVID-19. International Journal of Hospitality Management, 102704. https://doi.org/10.1016/j.ijhm.2020.102704

[14] Chen, CF, \& Tsai, DC (2007a). How destination image and evaluative factors affect behavioral intentions? Tourism Management, 28(4), 1115-1122. https://doi.org/10.1016/j.tourman.2006.07.007

[15] Chi, CGQ, \& Qu, H. (2008). Examining the structural relationships of destination image, tourist satisfaction and destination loyalty: An integrated approach. Tourism Management, 29(4), 624-636. https://doi.org/10.1016/j.tourman.2007.06.007

[16] Chia, SKS, Lo, MC, Razak, Z. Bin, Wang, YC, \& Mohamad, AA (2021). Impact of destination image on tourist satisfaction: The moderating effect of information technology (It). Geojournal of Tourism and Geosites, 34(1), 88-93. https://doi.org/10.30892/gtg.34112-623

[17] Chin, WW (1998). The partial least squares approach to structural equation modeling. Modern Methods for Business Research, 295(2), 295-336.

[18] oban, S. (2012). The effects of the image of destination on tourist satisfaction and loyalty: The case of Cappadocia. European Journal of Social Sciences, 29(2), 222-232.

[19] Cooper, MD (2000). Towards a model of safety culture. Safety Science, 36(2), 111-136. https://doi.org/10.1016/S09257535(00)00035-7

[20] Cozma, AC, \& Coros, MM (2017). Tourism Development in Rodna Mountains National Park: the Public Administration, a Key Stakeholder. Journal of Tourism - Studies and Research in Tourism, 24(24), 89-94.

[21] Crompton, JL (1979). Motivations for pleasure vacation. Annals of Tourism Research, 6(4), 408-424. https://doi.org/10.1016/01607383(79)90004-5

[22] Del Bosque, IR, \& San Martín, H. (2008). Tourist satisfaction a cognitive-affective model. Annals of Tourism Research, 35(2), 551-573. https://doi.org/10.1016/j.annals.2008.02.006

[23] Dewa, CB (2019). The Effect of Service Quality on the Image of the Ketingan Tourism Village Destination with Electronic Word of Mouth as a Mediating Variable. Khasanah Ilmu - Journal of $\begin{array}{lll}\text { Tourism and } & \text { Culture, }\end{array}$ https://doi.org/10.31294/khi.v10i2.6553

[24] Diwangkara, NK, Sari, SR, \& Rukayah, RS (2020). Tourism Development of Baturraden Region. ARCADE Journal of Architecture, 4(2), 120. https://doi.org/10.31848/arcade.v4i2.431

[25] Faizal Hamzah, OIBH (2005). The Effect of Excellent Service on Loyalty of Guests Staying at Sumber Alam Resort Garut. Journal $\begin{array}{lll}\text { of } \quad \text { Tourism, } & \text { 89-97. }\end{array}$ https://ejournal.bsi.ac.id/ejurnal/index.php/jp/article/view/896

[26] Gadoo, MR (2017). Measuring the Impact of Service Quality on Tourist Satisfaction : A Study of Tourism Industry of Kashmir. 5(4), 2514-2518.

[27] Game, ENT (2018). Tourist satisfaction, image, and loyalty from an interregional perspective: An analysis of neighboring areas with distinct characteristics. Sustainability (Switzerland), 10(4). https://doi.org/10.3390/su10041283

[28] Hamzah, F., \& Hariyanto, OIB (2015). The Effect of Excellent Service on Guest Loyalty Staying at Sumber Alam Resort Garut. Journal of Tourism, 2(2), 89-97.

[29] Hanif, A., Kusumawati, A., \& Mawardi, M. (2016). The Effect of Destination Image on Tourist Satisfaction and Its Impact on Tourist Loyalty (Study on Archipelago Tourists who Visit Batu City). Journal of Business Administration S1 Universitas Brawijaya, 38(1), 44-52.

[30] Hermawan, H. (2018). The Effect of Service Quality on Tourist Satisfaction and Its Impact on Loyalty. Upazila Dewantara, 2(2), 99-111. https://doi.org/10.26460/mmud.v2i2.3088

[31] Hidayatullah, S., Windhyastiti, I., Patalo, RG, \& Rachmawati, IK (2020). Destination Image: Its Effect on Satisfaction and Loyalty of Tourists Visiting Mount Bromo. Journal of Management and
Entrepreneurship,

$8(1)$

https://doi.org/10.26905/jmdk.v8i1.4246

96-108.

[32] Hui, ECM, \& Zheng, X. (2010). Measuring customer satisfaction of FM service in housing sector: A structural equation model approach. Facilities, 28(5-6), 306-320. https://doi.org/10.1108/02632771011031538

[33] Ihshani, D. (2005). Analysis of consumer satisfaction on tourism attributes Cangkuang Garut, West Java. Bogor Agricultural University. http://repository.ipb.ac.id/handle/123456789/11549

[34] Janchai, N., Baxter, G., \& Srisaeng, P. (2020). The effects of destination image on tourist satisfaction: The case of don-wai floating market in Nakhon Pathom, Thailand. Academica Turistica, 13(2), 139-151. https://doi.org/10.26493/23354194.13.139-151

[35] Kannan, VR, \& Tan, KC (2005). Just in time, total quality management, and supply chain management: Understanding their linkages and impact on business performance. Omega, 33(2), 153162. https://doi.org/10.1016/j.omega.2004.03.012

[36] Khan, MJ, Chelliah, S., \& Ahmed, S. (2017). Factors influencing destination image and visit intention among young women travelers: role of travel motivation, perceived risks, and travel constraints. Asia Pacific Journal of Tourism Research, 22(11), 1139-1155. https://doi.org/10.1080/10941665.2017.1374985

[37] Khotimah, K., \& Wilopo, W. (2017). Strategy for Development of Cultural Tourism Destinations (Case Study on Trowulan Site Area as Featured Cultural Tourism in Mojokerto Regency). Journal of Business Administration S1 Universitas Brawijaya, 42(1), 56-65.

[38] Khuong, MN, Phuong, NT, \& Diem Chau, TN (2016). The Effects of Travel Service Quality on Organization Perceived Value, Satisfaction and Word-Of-Mouth-A study in Ho Chi Minh City, Vietnam. Review of European Studies, 8(3), 36. https://doi.org/10.5539/res.v8n3p36

[39] Kolobova, A., Yakhvarova, E., Kirilushkina, I., Pashinina, E., \& Baurova, Y. (2021). On the Question of Russian Regions Consumer Markets, Focused on Tourists (on the Results of Sociological Research). SHS Web of Conferences, 93, 04008. https://doi.org/10.1051/shsconf/20219304008

[40] Kong, WH, Loi, KI, \& Xu, J. (2020). Investigating Destination Loyalty through Tourist Attraction Personality and Loyalty. Journal of China Tourism Research. https://doi.org/10.1080/19388160.2020.1862011

[41] Kotler, P., \& Keller, KL (2016). Marketing Management, 15th Edition. Pearson Education, Inc.

[42] Králiková, A., Peruthová, A., \& Ryglová, K. (2020). Impact of destination image on satisfaction and loyalty. Acta Universitatis Agriculturae et Silviculturae Mendelianae Brunensis, 68(1), 199209. https://doi.org/10.11118/actaun202068010199

[43] Krasnokutskiy, PA, Kulchittskij, AV, Perova, TV, Bystrova, NV, \& Khizhnaya, AV (2016). The main trends and prospects of development of international tourism. International Journal of Economics and Financial Issues, 6(8Special Issue), 257-262.

[44] Le, HBH, \& Le, TB (2020). Impact of destination image and satisfaction on tourist loyalty: Mountain destinations in Thanh Hoa province, Vietnam. Journal of Asian Finance, Economics and Business, 7(4), https://doi.org/10.13106/JAFEB.2020.Vol7.No4.185

[45] Leguina, A. (2015). A primer on partial least squares structural equation modeling (PLS-SEM). In International Journal of Research \& Methods in Education (Vol. 38, Issue 2). SAGE Publications, Inc. https://doi.org/10.1080/1743727x.2015.1005806

[46] Lesmana, R., \& Hasbiyah, W. (2019). Analysis Model of Satisfaction and Loyalty of Local Tourists Case Study on the Thousand Islands Tourism Object, Jakarta. JIMF (Forkamma $\begin{array}{llll}\text { Management Scientific } & \text { Journal), }\end{array}$ https://doi.org/10.32493/frkm.v2i3.3396

[47] Muis, MR, Gultom, DK, Jufrizen, J., \& Azhar, ME (2020). Word of Mouth Electronic Model: Destination Image, Tourist Satisfaction and Loyalty. Scientific Journal of Management and Business, 21(1), 1-19. https://doi.org/10.30596/jimb.v21i1.3694

[48] Mutiara, S., Hamid, RS, \& Suardi, A. (2020). The Influence of Service Quality, Price Perception and Taste on Consumer 
Satisfaction. Jessa (Journal of Islamic Economics \& Economics), 4(1), 411-427. https://doi.org/10.36778/jesya.v4i1.300

[49] Oliver, RL, \& DeSarbo, WS (1988). Response Determinants in Satisfaction Judgments. Journal of Consumer Research, 14(4), 495. https://doi.org/10.1086/209131

[50] Osti, L., \& Nava, CR (2020). Loyal: To What Extent? A shift in destination preference due to the COVID-19 pandemic. Annals of Tourism Research Empirical Insights, 1(1), 100004. https://doi.org/10.1016/j.annale.2020.100004

[51] Păcurar, CM, Albu, RG, \& Pcurar, VD (2021). Tourist route optimization in the context of the covid-19 pandemic. $\begin{array}{lll}\text { Sustainability } & \text { (Switzerland), }\end{array}$ https://doi.org/10.3390/su13105492

[52] Parasuraman, A., Zeithaml, VA, \& Berry, LL (1985). A Conceptual Model of Service Quality and Its Implications for Future Research. Journal of Marketing, 49(4), 41. https://doi.org/10.2307/1251430

[53] Prasetya, Y., \& Suryadi. (2020). Journal of Diversified Management Journal of Diversified Management. Journal of Management, 1(1), 1-11.

[54] Prayag, G., \& Ryan, C. (2012). Antecedents of tourists' loyalty to Mauritius: The role and influence of destination image, place attachment, personal involvement, and satisfaction. Journal of Travel Research, 51(3), 342-356. https://doi.org/10.1177/0047287511410321

[55] Qu, H., Kim, LH, \& Im, HH (2011). A model of destination branding: Integrating the concepts of the branding and destination image. Tourism Management, 32(3), 465-476. https://doi.org/10.1016/j.tourman.2010.03.014

[56] Ramseook-Munhurrun, P., Seebaluck, VN, \& Naidoo, P. (2015). Examining the Structural Relationships of Destination Image, Perceived Value, Tourist Satisfaction and Loyalty: Case of Mauritius. Procedia - Social and Behavioral Sciences, 175(April), 252-259. https://doi.org/10.1016/j.sbspro.2015.01.1198

[57] Ryu, K., Lee, HR, \& Kim, WG (2012). The influence of the quality of the physical environment, food, and service on restaurant image, customer perceived value, customer satisfaction, and behavioral intentions. International Journal of Contemporary Hospitality Management, 24(2), 200-223. https://doi.org/10.1108/09596111211206141

[58] Santouridis, I., \& Trivellas, P. (2010). Investigating the impact of service quality and customer satisfaction on customer loyalty in mobile telephony in Greece. TQM Journal, 22(3), 330-343. https://doi.org/10.1108/1742731011035550

[59] Saragih, R. (2015). The Effect of Service Quality on Corporate Image and Customer Satisfaction (Survey of Tourists at Selecta Batu Recreational Park). Journal of Business Administration S1 Universitas Brawijaya, 24(2), 86090.

[60] Sekaran, U. (2017). Research Methods For Business - Book 2 (p. 284).

[61] Sheller, M. (2020). Reconstructing tourism in the Caribbean: connecting pandemic recovery, climate resilience and sustainable tourism through mobility justice. Journal of Sustainable Tourism, 1-14. https://doi.org/10.1080/09669582.2020.1791141

[62] Silnov, DS, \& Tarakanov, OV (2015). Assessing the stability of antivirus software and data protection means against erroneous outcomes. International Journal of Applied Engineering Research, 10(19), 40342-40349.

[63] kare, M., Soriano, DR, \& Porada-Rochoń, M. (2021). Impact of COVID-19 on the travel and tourism industry. Technological Forecasting and Social Change, 163, 120469. https://doi.org/10.1016/j.techfore.2020.120469
[64] Studies, G. (2021). Journal of Geopolitics, Geostrategic, and Geoeconomic Studies Vol. 1, No. 1, February 2021. 1(1), 24-37.

[65] Sugawara, E., \& Nikaido, H. (2014). Properties of AdeABC and AdeIJK efflux systems of Acinetobacter baumannii compared with those of the AcrAB-TolC system of Escherichia coli. Antimicrobial Agents and Chemotherapy, 58(12), 7250-7257. https://doi.org/10.1128/AAC.03728-14

[66] Sugiama, AG (2011). Ecotourism: Development of Nature Conservation-Based Tourism. In Bandung, Guardaya Intimarta (Vol. 17). Guardia Intimate.

[67] Sugiyono. (2017). Quantitative, Qualitative, and R\&D Research Methods. Alphabet.

[68] Sukmadinata Syaodih, N. (2009). Educational Research Methods. In Bandung: Faithful Library. Rosdakarya Youth.

[69] Sun, X., Geng-Qing Chi, C., \& Xu, H. (2013). Developing destination loyalty: The case of Hainan island. Annals of Tourism Research, 43, 547-577. https://doi.org/10.1016/j.annals.2013.04.006

[70] Sunaryo, B. (2013). Tourism Destination Development Policy: Concept and Application. Java Media.

[71] Suprihatin, W. (2020). Analysis of Tourist Consumer Behavior in the Era of the Covid-19 Pandemic (Case Study of Tourism in West Nusa Tenggara). Bestari Journal, 19(1), 56-66.

[72] Suwena, IK (2010). The Format of Future Tourism" in Sustainable Tourism in a Global Crisis Swirl. In Denpasar: Publisher Udayana University Press. Matter. Udayana University Press.

[73] Tabri, N., \& Elliott, CM (2012). Principles and Practice of Structural Equation Modeling. In Canadian Graduate Journal of Sociology and Criminology (3rd ed., Vol. 1, Issue 1). The Guildford Press. https://doi.org/10.15353/cgjsc-rcessc.vli1.25

[74] Ummasyaroh, \& Setiawan, H. (2018). Effects of Destination Image, Tourist Motivation, Service Quality and Perceived Value on Tourist Satisfaction and Loyalty. Sriwijaya International Journal of Dynamic Economics and Business, 2(3), 225-236.

[75] Wachyuni, SS, \& Kusumaningrum, DA (2020). The Effect of COVID-19 Pandemic: How are the Future Tourist Behavior? Journal of Education, Society and Behavioral Science, 33(1), 6776. https://doi.org/10.9734/jesbs/2020/v33i430219

[76] Wanda, IBK, \& Pangestuti, E. (2018). The effect of developing a tourist destination component on visitor satisfaction (Survey of Visitors to the Trowulan Site). Journal of Business Administration, 55(3), 83-91.

[77] Wibowo, R., Alvianna, S., Hidayatullah, S., Astuti, W., \& Setioko, D. (2021). Analysis of the Influence of Tourist Destinations and Service Quality on Tourist Satisfaction Visiting the Jawa Timur Park in the New Normal Era. In International Journal of Innovative Science and Research Technology (Vol. 6, Issue 1). www.ijisrt.com295

[78] Yoeti, A. ok. (2015). Introduction to Tourism Science. Bandung.Space. Andi Publisher.

[79] Yu, C., \& Hwang, YS (2019). Do the social responsibility efforts of the destination affect the loyalty of tourists? Sustainability (Switzerland), 11(7), 11. https://doi.org/10.3390/su11071998

[80] Zhang, D., Qi, H., \& Qi, N. (2021). Transportation image: Placebased vehicles for destination branding. Journal of Destination Marketing and Management, 19, 100541. https://doi.org/10.1016/j.jdmm.2020.100541

[81] Zulzilah, S., Prihantoro, E., \& Masitoh, S. (2019). The Image Tourism Destinations of Bandung in Social Media Network. International Journal of Multicultural and Multireligious Understanding, 6(4), 72-83. 